\title{
Acid stress response in Saccharomyces cerevisiae involves ionic homeostasis and calcium signaling pathway
}

\author{
Marcos Vinicius Almeida*, Júlio César Rosa, Heloá Queirós, Rogelio Brandão, leso Castro \\ From 5th Congress of the Brazilian Biotechnology Society (SBBIOTEC) \\ Florianópolis, Brazil. 10-14 November 2013
}

To maintain their productive capacity, yeasts cells need to adapt to environmental changes that occur during production process. Acid stress response is of interest, because such exposure occurs under industrial conditions, such as the acidic treatment before cell recycling in fermentation process. Resembling the response to weak organic acids, resistance to inorganic acids exposure involves changes in the membrane conductivity to $\mathrm{H}^{+}$, active extrusion of acid from the cell and gene expression modulation. We previously investigated cellular tolerance to $\mathrm{HCl} \mathrm{pH} \mathrm{2,0} \mathrm{and} \mathrm{suggested} \mathrm{that} \mathrm{the} \mathrm{systems} \mathrm{involved} \mathrm{in}$ the maintaining of the plasma membrane potential (PMA1p $\mathrm{H}^{+}$-ATPase and secondary transporter systems) were linked to the acid stress response [1]. The present study focused on plasma membrane $\mathrm{H}^{+}$-ATPase participation and calcium signaling events observed in response to acid stress. To evaluate cell viability, yeast strains were grown in YPD medium up to $\mathrm{OD}_{600 \mathrm{~nm}} 1,0$. Cells were harvested by centrifugation and washed with YP medium. They were suspended in $\mathrm{HCl}$ aqueous solution ( $\mathrm{pH} 2.0$ ) supplemented with $86 \mathrm{mM} \mathrm{NaCl}$ and incubated in orbital shaker at $30^{\circ} \mathrm{C}$. Aliquots were collected at $0,10,30$ and 60 minutes, washed, diluted and spotted onto YPD-agar. Colonies were counted after 48 hours. To determine cell buffer capacity, cells were grown and harvested as described above and exposed to acid pulses with small volumes of $\mathrm{HCl}$. Resultant $\mathrm{pH}$ were measured with a $\mathrm{pH}$ meter. ENA1 gene was cloned in a single copy plasmid, p417CYC, and in a multicopy plasmid, p427TEF. Strain LBCM479 (ena1-4A) was transformed with both constructions and $\mathrm{H}^{+}$-ATPase activity was measured as previously described [2], before and after a pulse acid.
Cytosolic calcium flow was monitored by the aequorin method [3] with some modifications. Yeasts carrying the apoaequorin-expressing plasmid, pVTU-AEQ, were harvested, washed with MES/Tris $0,1 \mathrm{M}$ buffer and incubated with $50 \mu \mathrm{M}$ of coelenterazin to reconstitute the functional aequorin. Cells were transferred to a luminometer tube. Light emission was monitored for 1 minute before and lasting until $10 \mathrm{~min}$ after acid pulses. Our results show that the extracellular buffering capacities of $S$. cerevisiae W303 and S. boulardii (probiotic strain) were similar, but S. cerevisiae W303 was more affected by acid pulses than S. boulardii. This yeast had a higher total buffer capacity and greater ability to maintain $\mathrm{pH}$ homeostasis after acid stress than S. cerevisiae W303. Activation in vivo of the $\mathrm{PM} \mathrm{H} \mathrm{H}^{+}$-ATPase by a pulse acid showed a correlation between ENA1 levels and the acidinduced $\mathrm{PM} \mathrm{H}^{+}$-ATPase activation. Acid pulses triggered very low calcium signals compared to glucose pulses. $\mathrm{KCl}$ pulse was used as negative control. The acid-induced transient elevation of cytosolic calcium was $\mathrm{pH}$ dependent and confirmed by the fluorescent calcium indicator Oregon Green ${ }^{\circledR} 488$ BAPTA-1, AM. Additionally, viability assays show that calcineurin and Crz1p are required to induce the acid-stress response. In conclusion, the present study shows that the internal $\mathrm{pH}$ of yeast is regulated by several systems, including the plasma membrane $\mathrm{H}^{+}$-ATPase, and that Ena1p has an important but undefined role in the cellular response to acid. We also demonstrated that the acid stress response is dependent on calcium signaling pathway.

Published: 1 October 2014 


\section{References}

1. Sant'Ana GS, Paes LS, Paiva AFV, Fietto LG, Tropia MJM, Giunchetti DSL,

Lucas C, Fietto JLR, Brandao RL, Castro IM: Protective effect of ions against cell death induced by acid stress in Saccharomyces. FEMS Yeast Res 2009, 9:701-712.

2. Becher dos Passos J, Vanhalewyn M, Brandao RL, Nicoli JR, Thevelein JM: Glucose-induced activation of plasma membrane $\mathrm{H}+$-ATPase in mutants of the yeast Saccharomyces cerevisiae affected in cAMP metabolism, CAMP-dependent protein phosphorylation and the initiation of glycolysis. BiochimBiophys Acta 1992, 1136:57-67.

3. Tisi R, Baldassa S, Belotti F, Martegani E: Phospholipase $C$ is required for glucose-induced calcium influx in budding yeast. FEBS Lett 2002, 520:133-138

doi:10.1186/1753-6561-8-S4-P193

Cite this article as: Almeida et al:: Acid stress response in Saccharomyces cerevisiae involves ionic homeostasis and calcium signaling pathway. BMC Proceedings 2014 8(Suppl 4):P193.

\section{Submit your next manuscript to BioMed Central} and take full advantage of:

- Convenient online submission

- Thorough peer review

- No space constraints or color figure charges

- Immediate publication on acceptance

- Inclusion in PubMed, CAS, Scopus and Google Scholar

- Research which is freely available for redistribution

Submit your manuscript at www.biomedcentral.com/submit 